\title{
SCIENTIFIC COMMUNICATION \\ Geographic distribution's ampliation of Chiroderma doriae Thomas (Mammalia, Chiroptera) in Brazil
}

\author{
Marcelo O. Bordignon
}

\begin{abstract}
Departamento de Ciências do Ambiente, Universidade Federal de Mato Grosso do Sul. Avenida Rio Branco 1270, 79304-020 Corumbá, Mato Grosso do Sul, Brasil.E-mail: batbull@bol.com.br
\end{abstract}

\begin{abstract}
The geographic distribution ampliation of Chiroderma doriae Thomas, 1891 is related in this note with a new record from Corumba City, in pantanal ecossistem of Mato Grosso do Sul State. This record extend the geographic range of $C$. doriae over $630 \mathrm{~km}$ westward in Brazil from literature last reccord. KEY WORDS. Bats from cerrado, Corumbá, geographic range, Pantanal.
\end{abstract}

RESUMO. Ampliação da distribuição geográfica de Chiroderma doriae Thomas (Mammalia, Chiroptera) no Brasil. Nesta nota é relatada a ampliação da distribuição geográfica de Chiroderma doriae Thomas, 1891 com um registro inédito na cidade de Corumbá, na região do Pantanal do Estado de Mato Grosso do Sul. Este relato estende a distribuição geográfica de $C$. doriae em mais de $630 \mathrm{~km}$ ao oeste, desde o seu último registro na literatura. PALAVRAS CHAVE. Corumbá, distribuição geográfica, morcegos do cerrado, Pantanal.

The Phyllostomid family bats is over wide distributed in Neotropic Region with about 140 species (EMmONs \& FeER 1990). Among the Phyllostomids, the big-eyed bat Chiroderma doriae Thomas, 1891 is a rare bat, in fact, their biology and behavior is poorly known in literature. This bat is distributed in eastern and southeastern Brazil (EMmONs \&FEer 1990, FonsECA et al. 1996) associated with rainforest vegetations. However, their range distribution was enlarged recently by GREGORIN (1998), demonstrated the few sampling to this especies.

During a study about bat fauna in September 2002, a male of $C$. doriae was collected in Urucum mountains $\left(19^{\circ} 11^{\prime}\right.$ 33.9"S, 53³6'59.0"W) from 30 km near Corumbá, Mato Grosso do Sul. This specimen was captured with a mist-net in forested area at $550 \mathrm{~m}$ (over sea level). The Urucum Mountains is a residual mountain formation of Paraguai's Pantanal sub-region (Silva \& AbDon 1988) and their around is explored by mineral iron industries. The local climate is tropical seasonal (Cwa-Aw of Koppen's classification) with a clearly defined rainy period (generally from October to March) and dry season (from April to September). The average month of temperature is $28^{\circ} \mathrm{C}$ (Alfonsi \& CAMARgo 1986). The vegetation is varied in Urucum from semi-decidual seasonal forest (about $100 \mathrm{~m}$ of altitude) to grassland (over $950 \mathrm{~m}$ of altitude) occurring since forest to Cerrado's formations and their floristic composition posses Chaco's, Cerrado's and Amazonian elements. The specimen collected is an adult male and are deposited in Zoological Collection of Universidade Federal de Mato Grosso do Sul, Corumbá (number Uru034). These distribution records extend the geographic range of $C$. doriae abouth $630 \mathrm{~km}$ westward from lasted record made by GREGORIN (1998) with specimens collected in 1992 from Brasilândia (Mato Grosso do Sul). This species is considered endemic from Brazil and in literature until now their geographic distribution (Fig. 1) are restricted to states of Rio de Janeiro (Aguiar 1998), São Paulo (Pedro \& Taddei 1997), Paraná (Vizzoto et al. 1976, Reis \& Peracchi 1998, Miretzki \& Margarido 1999), southeastern Minas Gerais (KoOPMAN 1982, FARIA 1996, Pedro \& Taddei 1998) and more recently in Pernambuco, northeast Brazil (Silva \& GuerRa 2000). This bat was considered vulnerable species (Aguiar \& Taddei 1995, Aguiar \& Pedro 1998) because some aspects as follow: restrict geographic distribution at eastern Brazil and their low abundance or record in bat inventories (GREGORIN 1998). However the present record, in addition to those provided by literature, show that $C$. doriae not posses a restricted distribution just southeastern in Brazil or in rain forests and xerophytic areas, but to now in pantanal ecosystem. This facts came justified the remote this species of endengered list ocurred in 2003, because today they ocurrence in Brazil is widerness knowledged.

\section{ACKNOWLEDGMENTS}

I'm grateful to Adriana de Oliveira França for help in field works and CNPq, Urucum Mineração (Vale do Rio Doce Company) for the logistical and financial support during the study. 


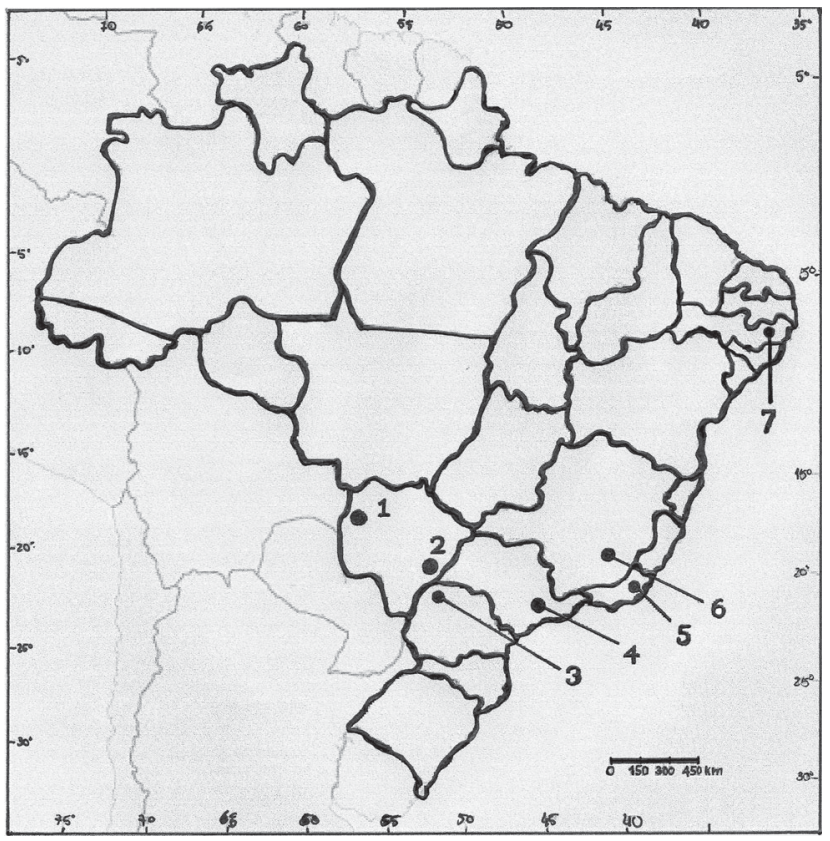

Figure 1. Records of Chiroderma doriae in Brazil: (1) Corumbá recorded in presente work, (2) Brasilândia by GREGorin (1998), (3) Paraná by Miretzki \& Margarido (1999), (4) São Paulo by Pedro \& Taddei (1997), (5) Rio de Janeiro by Aguiar (1998), (6) Minas Gerais by Pedro \& Taddei (1998), (7) Pernambuco by Silva \& Guerra (2000).

\section{REFERENCES}

Aguiar, L.M.S. \& V.A. TAdDEI. 1995. Workshop sobre a conservação dos morcegos brasileiros. Chiroptera Neotropical, Brasília, 1 (2): 24-30.

Aguiar, L.M.S. 1998. Espécies de morcegos ameaçadas de extinção no Estado do Rio de Janeiro. Chiroptera Neotropical, Brasília, 4 (1): 91-92.

Aguiar, L.M.S. \& W.A. Pedro. 1998. Chiroderma doriae, p. 66-68. In: A.B.M. Machado; G.A.B.Fonseca; R.B. Machado; L.M.S. Aguiar \& L.V. Lins (Eds). Livro Vermelho das Espécies Ameaçadas de Extinção da Fauna de Minas Gerais. Belo Horizonte, Fundação Biodiversitas, 360p.

Alfonsi, R.R. \& M.B.P. Camargo. 1986. Condições climáticas para a região do Pantanal Mato-grossense. Simpósio sobre recursos naturais e socioeconômicos do pantanal, Corumbá. Brasília, Embrapa, vol. 1, p. 29-42.

EMmONs, L.H. \& F. FeER. 1990. Neotropical Rainforest Mammals: a field guide. Chicago, The University of Chicago Press, 290p.

FARIA, D.M. 1996. Food resource utilization by a Phyllostomid phytophagous bat guild at the Santa Genebra Reserve, Campinas, SP, Brazil. Chiroptera Neotropical, Brasília, 2 (1): 43.

Fonseca, G.A.B.; G. Herrmann; Y.L.R. Leite; R.A. Mittermeier; A.B. Rylands \& J.L. Patton. 1996. Lista anotada dos mamíferos do Brasil. Occasional Papers in Conservation Biology, Washington, 4: 1-38.

Gregorin, R. 1998. Extending geographic distribution of Chiroderma doriae Thomas, 1891 (Phyllostomidae, Stenodermatinae). Chiroptera Neotropical, Brasília, 4 (2): 98-99.

Koopman, K.F. 1982. Biogeography of the bats of South America. Pymatuning Laboratory of Ecology Especial Publication, Linesville, 6: 273-302.

Miretzki, M. \& T.C.C. Margarido. 1999. Morcegos da Estação Ecológica do Caiuá, Paraná (Sul do Brasil). Chiroptera Neotropical, Brasília, 5 (1-2): 105-108.

Pedro, W.A. \& V.A. TAddeI. 1997. Taxonomic assemblage of bats from Panga Reserve, southeastern Brazil: abundance patterns and trophic relations in the Phyllostomidae (Chiroptera). Boletim do Museu de Biologia Mello Leitão, Belém, 6: 321.

Pedro, W.A. \& V.A. TaddeI. 1998. Bats from southwestern Minas Gerais, Brazil (Mammalia: Chiroptera). Chiroptera Neotropical, Brasília, 4 (1): 85-87.

Reis, N.R. \& A.L. Peracchi. 1998. Updated list of the chiropterians of the City of Londrina, Paraná, Brazil. Chiroptera Neotropical, Brasília, 4 (2): 96-98.

Silva, J.S.V. \& M.M. Abdon. 1988. Delimitação do Pantanal Brasileiro e suas sub-regiões. Pesquisa Agropecuária Brasileira, Brasília, 33: 1703-1717.

Silva, L.A.M. \& GuerRA, D.Q. 2000. Bats from a remnant atlantic forest in northeast Brazil. Chiroptera Neotropical, Brasília, 6 (1-2): 125-126.

Vizzoto, L.D.; V.A. Taddei; A. Cais \& O. Renesto. 1976. Nota preliminar sobre morcegos do Sudoeste de São Paulo e Norte do Paraná. Ciência \& Cultura, Rio de Janeiro, 28 (7): 432-433.

Received in 06.IV.2005; accepted in 22.XI.2005. 